\title{
室・ダクト系の空気調和シミュレーションに関する研究 STUDY ON AIR CONDITIONING SIMULATION FOR ROOMS AND DUCTS SYSTEM
}

\author{
山下一彦*, 後藤立夫**, 山崎 均*** \\ Kazuhiko YAMASHITA, Tatsuo GOTOH and Hitoshi YAMAZAKI
}

\begin{abstract}
In design for air conditioning equipment, it is important to grasp in advance whether exhibit equipment's design abilities or not So, we take up rooms and ducts system in air conditioning equipment, and apply to estimate calculation of room pressure and airflow for room other than clean room. This paper refers to make clear various characteristics of control, at the same time to make an estimate of room pressure and airflow by simulation. Parameters of the subject are heat characteristics of rooms, air temperature and humidity, special quality of control and wind environment.
\end{abstract}

Keywords : Simulation, Rooms and ducts system, Air conditioning, Room pressure and airflow estimate Convergence calculation method, Control シミュレーション, 室・ダクト系, 空調, 室圧・風量予測, 収束計算法, 制御

\section{1.はじめに}

空気調和設備設計において, 余裕を持たせた設備とすることは望 ましいことである。しかし，エネルギーを自由に使える時代からエ ネルギーを節約し，自然環境を守ることが重要なテーマとなった近 年では, 豊富な設備機器を使用しながらも, より経済的で質の高い 設計が要求されるようになりつつあるのが現実である。この問題を 踏まえれば，設計された設備が，期待した能力を発揮するかどうか 事前に把握することは重要な問題解決の手段である。そこで本報告 では，空気調和設備のなかで室・ダクト系を採り上げ，この室圧・ 風量予測計算をクリーンルーム ${ }^{1) ~ 33 ~}$ 以外の室の空調に適用して, 室 圧・風量予測を実行し，また同時に制御の種々の特性をシミュレー ション ${ }^{4}$ で明らかにしようとするものである。対象とする変数項目 は, 室の熱特性, 空気温湿度, 制御特性 ${ }^{5)}$ のほか風環境の変動であ る。

\section{2. 室圧・囷量予測計算法の概要}

通風・隙間開口の圧力損失は，DARCY-HYSBACH の式，すなわち局

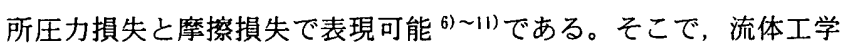
の基礎知識とダクト設計用局所圧力損失データを利用して, 通風 ·
隙間および機械換気を含む室・ダクト系における室圧・風量計算予 測システムを関連ある在来型計算アルゴリズムとしてまとめた ${ }^{12) ~ ~}$ 14)。

室・ダクト系において, $i$ 室の圧力は, 室の静圧を $p_{i}$ とすると,

$$
p_{i}+\rho \cdot g \cdot h_{i}
$$

と表現できる。1 スペースにおいて上下に温度分布がなければ, $h_{i}$ は室の高さの平均值である。ここでの計算法は, 室またはスペース に温度分布はないとする。温度分布が無視できない室については室 を分割して計算可能であるが, 分割したスペース毎の圧力一定を仮 定するので, それ以上の精度は要求できない。 $i$ 室に流入する送風 機器があるときの $i$ 室の圧力は,

$$
p_{i}-M S P_{i}+\rho \cdot g \cdot h_{i}
$$

と表現する。 $i$ 室と接続する $j$ 室と $i$ 室の圧力差 $\Delta p_{i, j}$ は, $j$ 室の 室圧が固定されたとすると, 送風機器のあるとき,

$$
\begin{aligned}
\Delta p_{i, j} & =M S P_{i}+p_{j}-p_{i}+g \cdot h_{i, j}\left(\rho_{j}-\rho_{i}\right) \\
& p_{i}: i \text { 室の静圧力 }[\mathrm{Pa}] \\
& p_{j}: j \text { 室の静圧力 }[\mathrm{Pa}] \\
& M S P_{i}: \text { 送風機器最大静圧 }[\mathrm{Pa}] \\
& \rho_{i}, \rho_{j}: \text { 空気密度 }\left[\mathrm{kg} / \mathrm{m}^{3}\right] \\
& h_{i, j}: \text { 接続管または隙間の中心高さ }[\mathrm{m}] \\
& g: \text { 重力加速度 }\left[\mathrm{m} / \mathrm{s}^{2}\right]
\end{aligned}
$$

* 新菱冷熱工業(侏)

** 新菱冷熱工業(㧣) 專務取締役・工博

*** 大分大学工学部建設工学科 教授. 工博
Shinryo Corporation

Shinryo Corporation Executive Director, Dr. Eng.

Prof., Dept. of Architectural Eng., Faculty of Eng., Oita Univ., Dr. Eng. 
となる。ここで, $M S P_{i}+p_{i}-p_{i}$ は $M S P_{i}$ が正のとき, 最大值は $M S P_{i}$, 最小値は 0 である（図一 1 参照）。送風機器のないときは, (3) 式において $M S P_{i}=0$ となる。 $j$ 室から $i$ 室に流入する流量を $q_{i, j}$ とすれば,

$$
\begin{aligned}
& \sum_{j=1}^{N} \rho_{i, j} \cdot q_{i, j}=0 \\
& q_{i, j}=\frac{2 \cdot \Delta p_{i, j}}{b_{i, j}+\sqrt{b_{i, j}{ }^{2}+4 \cdot a_{i, j} \cdot \Delta p_{i, j}}}
\end{aligned}
$$

となる。 $N$ は当該室の吹出口, 送風機, 隙間の総量であり, $a_{i, j}$ お よび $b_{i, j}$ は, DARCY-FYSBACH の式から,

$$
\Delta p=a \cdot q^{2}+b \cdot q
$$

と表現したときの係数 $a, b$ である。計算速度を速めるために隙間。 ダクト等の面積は係数 $a, b$ に含ませている。ただし, 密度と阽性係 数は状態で変化するので後で処理する（第 3 章で後述する）。送風 機のように係数 $b$ が負になるときには， $\Delta p_{i, j}$ の絶対值はとらない。 そのかわり，送風機吸込側は MSP が負であるので, $\Delta p_{i, j}$ の代わり に- $\Delta p_{i, j}$ とする。

$$
\begin{gathered}
M S P_{i} \geq 0[\mathrm{~Pa}] \text { のとき }(i \text { : 当該室 }) \\
\Delta p_{i, j}=M S P_{i}+p_{i}-p_{i}+g \cdot h_{i, j} \cdot\left(\rho_{j}-\rho_{i}\right) \\
M S P_{j}=-M S P_{i}, h_{i, j}=h_{j, j} \text { であり }(j: \text { 当該室 }) \\
\Delta p_{j, i}=M S P_{j}+p_{i}-p_{j}+g \cdot h_{j, i} \cdot\left(\rho_{i}-\rho_{j}\right)
\end{gathered}
$$

である。係数 $a, b$ について, 隙間・開口を平行平板とする場合,

$$
a=\frac{C \cdot \rho}{2 \cdot D^{2}}, \quad b=\frac{12 \cdot L \cdot \mu}{D^{3}}
$$

層流の隙間・開口を円管近似する場合,

$$
a=\frac{8 \cdot C \cdot \rho}{\pi^{2} \cdot D^{4}}, \quad b=\frac{128 \cdot L \cdot \mu}{\pi \cdot D^{4}}
$$

乱流円管の場合,

$$
\begin{gathered}
a=\frac{8 \cdot C \cdot \rho}{\pi^{2} \cdot D^{4}}+t_{1} \cdot \frac{8 \cdot L \cdot \rho}{\pi^{2} \cdot D^{5}}, \quad b=t_{2} \cdot \frac{2 \cdot L \cdot \mu}{\pi \cdot D^{4}}, \quad c=t_{3} \cdot \frac{L \cdot \mu^{2}}{2 \cdot D^{3} \cdot \rho} \\
C: \text { 局所圧力損失係数 } \\
D: \text { 平行平板隙間間隔あるいは円管直径 }[\mathrm{m}] \\
L: \text { 平行平板隙間奥行きあるいは円管長さ }[\mathrm{m}] \\
\mu: \text { 粘性倸数 }[\mathrm{kg} /(\mathrm{m} \cdot \mathrm{s})]
\end{gathered}
$$

である。 $t_{1}, t_{2}, t_{3}$ は, 乱流における摩擦係数 $\lambda$ を

$$
\lambda=t_{1}+\frac{t_{2}}{\mathrm{Re}}+\frac{t_{3}}{\mathrm{Re}^{2}}
$$

としたときのもので, 3 つの Re 数（レイノルズ数）とダクトの粗 度から計算できる数值である。 Re 数は表一 1 に示すように段階的 に設定した。なお，表ー 1 に示した $\mathrm{k}$ の数値は第 3 章で述べる CHANNEL 構造体の配列番号である。また，cについても第 3 章で述 ベる。

表 $-1 \quad \operatorname{Re}$ 数の段階設定値
\begin{tabular}{|l|c|}
\hline $\operatorname{Re}<1000$ & $\mathrm{k}=0$ \\
\hline $1000 \leqq \operatorname{Re}<8400$ & $\mathrm{k}=1$ \\
\hline $8400 \leqq \operatorname{Re}<40000$ & $\mathrm{k}=2$ \\
\hline $40000 \leqq \operatorname{Re}<200000$ & $\mathrm{k}=3$ \\
\hline $200000 \leqq \operatorname{Re}<1000000$ & $\mathrm{k}=4$ \\
\hline $\operatorname{Re} \geqq 1000000$ & $\mathrm{k}=5$ \\
\hline
\end{tabular}

図ー 1 に示すように送風機器の縦軸に静圧, 横軸に風量をとったと きの特性曲線における軸が負側になるように選定すれば，風量 $q_{i, j}$ は(5)式で計算できる。

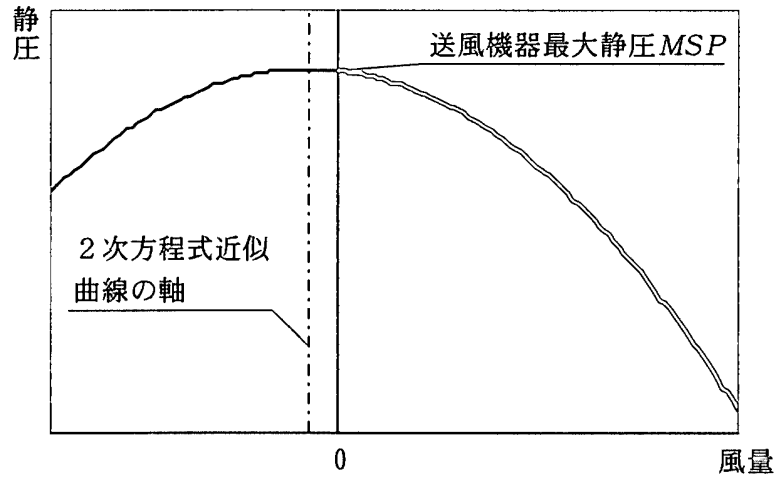

図-1 送風機器の特性曲線

以上から， $p_{i}$ を計算する式は，

$$
p_{i}=\frac{\sum_{i=1}^{N}\left(\rho_{i, j} \cdot \frac{2 \cdot\left(\Delta p_{i, j}-p_{i}\right)}{b_{i, j}+\sqrt{b_{i, j}{ }^{2}+4 \cdot a_{i, j} \cdot \Delta p_{i, j}}}\right)}{\sum_{i=1}^{N}\left(\rho_{i, j} \cdot \frac{2}{b_{i, j}+\sqrt{b_{i, j}{ }^{2}+4 \cdot a_{i, j} \cdot \Delta p_{i, j}}}\right)}
$$

となる。ただし， $\Delta p_{i, j}$ には $p_{i}$ が含まれているので, 绯り返し演算 になる。なお,この計算式は，

$$
\Delta p=\left(C+\lambda \cdot \frac{L}{D}\right) \cdot \frac{1}{2} \cdot \rho \cdot v^{2}
$$

から導いているので, 隙間風量計算の局所圧力損失係数 $C$ が正のと き， $\Delta p$ は常に正であるので, $\Delta p_{i, j}$ についてはそのことを考慮して 計算する。この収束式は,

$$
\frac{d q_{i, j}}{d p_{i}}=-\frac{1}{\sqrt{b_{i, j}{ }^{2}+4 \cdot a_{i, j} \cdot \Delta p_{i, j}}}<0
$$

が成り立つので収束が容易である。

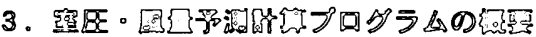

室圧・風量予測計算で必要な室の空気の性質は, 室温, 室の絶対 湿度, 室圧力であり, それに換気風量計算には, 室に流入する質量 風量と開口数が必要である。各開口は, 吹出口・吸込口, 空・ドア のあけた状態としての開口, 閉めた状態としての隙間がある。また， 換気扇・送風機器などがある。吹出口・吸込口は, 局所圧力損失を 伴うダクトが接続される。ダクトの摩擦損失は, ダクト直径, 内表 面の粗度とダクト長さが必要である。大きな開口は通風と同じ局所 圧力損失，隙間は断面が円形・平行平板としての層流近似で表現す る。送風機器は, 静圧風量特性曲線之近似させるための平行平板ま たは円管隙間が接続される。これらの開口は, 温度差の影響を計算 するために, 開口中心高さが必要である。縦に長い隙間は 2 分割以 上に分割しておく。

これらの項目をC言語の構造体と構造体ポインタで記述すると, struct room 1

char name [81];

/*漢字 17 文字*/ 
double spw, spd, sph, vlm;

double hq;

double wv;

double water

char a [8];

double $t$;

double $w$;

double $\mathrm{p}$;

double $\mathrm{q}$;

int $\mathrm{n}$;

struct channel $*$ link;

\} *rm;

struct channel \{

double a $[6], b[6], c[6]$;

double e; /*粗度*/

double msp; $\quad / *$ 送風・換気装置の最大静圧 $* /$

double d; / / 平行平板隙間幅またはダクト直径ま/

double width; /*隙間長さまたはダクト長さま/

double height; /*隙間位置高さ, 隙間高さの中央値*/

double q; / / 隙間風量 $*$ /

int link; /*接続隣室番号*/

char section; $/ * \mathrm{~W}:$ 矩形, $\mathrm{D}:$ 円形, $\mathrm{F}:$ 送風・換気装置 $* /$

char branch; /*S: 直進, b : 分岐*/

struct channel *next;

) *p;

なお, 円形ダクトが接続される場合, CHANNEL 構造体中の隙間は ダクトに読み替える。室を中心に, 吹出口, 送風機器, 隙間, 開口 が接続される。室はいわゆる室と全圧で示された仮想室（以下室と 総称することがある) である。室から室までの一列の CHANNEL は， 1 つの構造体に対応している。一列の腺間の場合, 出口の局所圧力 損失係数, 隙間幅, 隙間長さ, 局所圧力損失係数, 隙間幅, 隙間長 さ, …⼊.入口の局所圧力損失係数となるが, 一組の直列チャン ネルで $\mu$ と $\rho$ は変化しないとし, また, 温度変化に対応させるため に, 後で残りの $C, L, D$ $L$ にり, デー夕読み込み時に一つにま とめる。そのためにダクトの場合は, ダクトの $\varepsilon / D(\varepsilon:$ 粗度 $[\mathrm{m}])$ が変化するごとに, そこに仮想室をおく。すなわち, 出口の局所圧 力損失係数, ダクト直径, ダクト長さ, 入り口の局所圧力損失係数, 仮想室, 出口の局所圧力損失係数, ダクト直径, ダクト長さ, 入り 口の局所圧力損失係数, 仮想室, ……とな。直径が変化する籄 所の局所圧力損失は, 基準化してあれば仮想室のどちらのダクトに おいてもよいが, そのダクトの所属する方に㯰く。仮想室とは, 動 圧を損失無く静圧に変換する装置のようなものである。デー夕読み 込み時に, ROOM, CHANNEL を確認した時点で, この構造体のメモリ を確保するようにしておけば, 100 の CHANNEL のある室と 2 の CHANNEL とが混在していても, 余分なメモリを消費しない。入力デ 一夕の記述は普段の仕事のジョブに近い形ですべきである。1つの CHANNEL は 2 つの室, または, 1 つの室と外部に接続している。し たがって, 一つの室に接続している全ての CHANNEL を室構造体は構 造体ポインターを介して線形りストとして持っているので, この
CHANNEL を室に流入するときのみ使用し, 流出するときにはそのダ クトまたは隙間の接するもう 1 つの室の CHANNEL データを使用す る。このようにすれば, 流れの方向による流量の違いも計算できる。 送風機器については, 最大最小值を設定する。

なお, CHANNEL 構造体の $a[k], b[k], c[k]$ の 6 つ配列は, 円形ダクトの場合 (9) 式で述べたように係数 $a, b, c$ を計算する ためのものである。係数 $a$ にはその温度の密度, 係数 $b$ にはその温 度の粘性係数を乗じる。係数 $c$ には粘性係数の 2 乗を密度で除した 值を乗ずる。すなわち,

$$
\begin{aligned}
& a=a[k] \cdot \rho \\
& b=b[k] \cdot \mu \\
& c=c[k] \cdot\left(\mu^{2} / \rho\right)
\end{aligned}
$$

である。したがって, CHANNEL の圧力差 $\Delta p$ が,

$$
\Delta p=p_{\text {nebour }}-p+M S P+\rho \cdot g \cdot h-c \quad[\mathrm{~Pa}]
$$

となるので風量 $q$ は (5) 式で計算できる。なお，(15) 式では乱流円 管における圧力の単位を持つ定数 $c$ が付加される。テー夕読み込み 時に $a, b, c$ を前処理しておく。層流及び送風機器では, $a$, $b, c$ は 1 組しか使用しない。

\section{4. 温湿度の叶等}

全ての室について, 単位時間に供給されるダクトからのエンタル ピー, 顕熱, 潜熱のそれぞれの総計を室から出ていく乾煤空気の重 量風量で除したもの，または室内で取得する乾燥空気の単位重量当 たりの量, または室の空気のエンタルピー, 温度, 湿度を $h, t$, $w$ とすると,

$$
\begin{aligned}
h=C_{\text {pair }}(t) \cdot t+w \cdot\left(R_{w}+C_{w v}(t) \cdot t\right) \\
C_{p a i r}: \text { 乾燥空気の比熱 }[\mathrm{kJ} /(\mathrm{kg} \cdot \mathrm{K})] \\
R_{w}: \text { 水蒸気の蒸発潜熱 }[\mathrm{kJ} / \mathrm{kg}] \\
C_{w v}: \text { 水蒸気の比熱 }[\mathrm{kJ} /(\mathrm{kg} \cdot \mathrm{K})]
\end{aligned}
$$

から，室のエンタルピー，温度，湿度が計算できる。

\section{5. 空铜機（AHU）の組み込み}

室圧・風量計算プログラムに組み込むためのAHUの入カデータ 例 ${ }^{15)}$ を示す。

[標準コイル]

管内径 $[\mathrm{mm}]: 14.6$

管外径 $[\mathrm{mm}]: 15.8$

管高さ方向ピッチ $[\mathrm{mm}]: 37.5$

フィン高さ [mm] : 11.8

フィン厚さ $[\mathrm{mm}]: 0.2$

フィンピッチ $[\mathrm{mm}]: 2.9$

フィンタイプ: p

フィン熱伝達率 : 175.0

コイル高さ $[\mathrm{m}]: 1.7$

コイル列数 : 8

コイル配列 : 千鳥形配列

結露水温度 : 1 
[空調機デー夕]

風量 $\left[\mathrm{m}^{3} / \mathrm{h}\right]: 18000.0$

入口側空気温度 $\left.{ }^{\circ} \mathrm{C}\right]: 28.0$ (状態により変化)

入口側空気相対湿度 [\%]：65.0（状態により変化）

入口側水温度 $\left[{ }^{\circ} \mathrm{C}\right]: 7.0$

水量 $[1 /$ min $]: 377$

テータ中の結露水温度は, クーリングコイルによる冷却計算におい て，エンタルピーによる冷却計算の際の結露水温度の取扱いについ てである。
0 : 考慮しない
$1:$ 冷却パイプの温度に近い
$2:$ 出口空気の温度と等しい
$3:$ 入口空気と出口空気の平均温度に等しい

以上の 4 通りが考えられる。結露水がどのように流れるか，また落 下した後, どの程度空気にさらされるか等の状涗が不確定なので, 実用的には考慮しない方が安全側である。

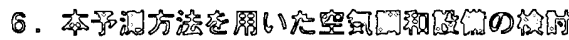

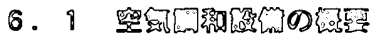

空気調和シミュレーションに用いた空調設備モテルの概要につ いで説明する。シミュレーションモデルは教室であり, 教室に対し て1台の空調機が設けられている。給気（SA：Supply Air）系統 および還気（RA：Return Air）系統には，それぞれ 2 台ずつの可 変風量装置 (VAV) が設置されており, SA-VAV-1 系統には吹出 口が 10 個，SA-VAV-2 系統には 12 個（SA-VAV-1, 2 系統とも各吹出 口の設計風量は $\left.818.2\left[\mathrm{~m}^{3} / \mathrm{h}\right]\right) ， \mathrm{RA}-\mathrm{VAV}-1$ 系統および RA-VAV-2 系 統には吸込口がそれぞれ 2 個ずつ（各吸込口の設計風量は $\left.4500\left[\mathrm{~m}^{3} / \mathrm{h}\right]\right)$ 設置されている。空調機の能力を表一 2 に示す。なお, 本報告での空調シミュレーションは冷房時をとりあげる。

表 -2 空調機能力

\begin{tabular}{|c|c|c|}
\hline \multirow[t]{2}{*}{ 送 風 機 } & 風 & $18000\left[\mathrm{~m}^{3} / \mathrm{h}\right]$ \\
\hline & 機 外 静 圧 & 60 [mmAq] \\
\hline \multirow[t]{2}{*}{ 還 風 機 } & 風 & $18000\left[\mathrm{~m}^{3} / \mathrm{h}\right]$ \\
\hline & 機 外 静 圧 & $40[\mathrm{mmAq}]$ \\
\hline \multirow[t]{5}{*}{ 冷水コイル } & 冷 却 能 力 & $135500[\mathrm{kcal} / \mathrm{h}]$ \\
\hline & 冷 & $377[1 / \mathrm{min}]$ \\
\hline & 入口側冷水温度 & $7\left[{ }^{\circ} \mathrm{C}\right]$ \\
\hline & 出口側冷水温度 & $13\left[{ }^{\circ} \mathrm{C}\right]$ \\
\hline & コイル 列 数 & 8 [列] \\
\hline 気 & & $6000\left[\mathrm{~m}^{3} / \mathrm{h}\right]$ \\
\hline
\end{tabular}

なお，空調機器は以下の内容で制御されている。

1)給気温度により冷水コイル 2 方弁の比例制御を行う。 なおシミュレーションは，2方弁制御のかわりに，冷水量の減少 はコイル列の減少に比例させる。

2) 室内湿度により加湿器の $0 \mathrm{~N} / \mathrm{OFF}$ 制御を行う。

3) 空調機立ち上がり時に外気ダンパを閉とし予冷/予熱を行う。

4) 空調機停止時, ダンパ，2 方弁，加湿弁のインターロック制御を 行う。

5) 外気取入れ有勃時還気ダンパを閉, 給気温度により外気ダンパの
比例制御を行う（外気冷房制御）。

6）VA V開度状態によりファン回転数制御を行う。

なおシミュレーションは, ファン回転数制御をV A Vの抵抗に置 き換える。

7)室内温度によりVAVの開度制御を行う。 また, 図ー 2 に概略のダクト平面図を示す。

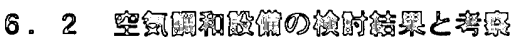

空調シミュレーションのためのデータ作成は以下の手順で行っ た。まずダクト図よりダクトデータ作成後, 空調機を組み込まず, システム全体を等温度として各系統の風量が, ほぼ設計值となるよ うに調整を行う。その結果, 教室の室圧が, 7.9 [mmAq] と非常に高 くなり，このままではドアが開かない等の整害の生じる恐れが考え られる。その原因は, 給気量より還気量が少ない量として設計され ているためと考えられる。このときの計算結果を表一 3 に示す。 表一 3 室圧・風量計算結果

\begin{tabular}{|c|l|rl|}
\hline \multicolumn{2}{|c|}{ 教室の室圧 } & 7.9 & {$[\mathrm{mmAq}]$} \\
\hline \multirow{4}{*}{ 風 } & $\mathrm{SA}-\mathrm{VA} \mathrm{V}-1$ & 7972 & {$\left[\mathrm{~m}^{3} / \mathrm{h}\right]$} \\
\cline { 2 - 4 } & $\mathrm{SA}-\mathrm{VA} \mathrm{V}-2$ & 9568 & {$\left[\mathrm{~m}^{3} / \mathrm{h}\right]$} \\
\cline { 2 - 4 } 量 & $\mathrm{RA} \mathrm{AA} \mathrm{V}-1$ & 8770 & {$\left[\mathrm{~m}^{3} / \mathrm{h}\right]$} \\
\cline { 2 - 4 } & $\mathrm{RA}-\mathrm{VA} \mathrm{V}-2$ & 8770 & {$\left[\mathrm{~m}^{3} / \mathrm{h}\right]$} \\
\cline { 2 - 4 } & $\mathrm{OA}$ & 6005 & {$\left[\mathrm{~m}^{3} / \mathrm{h}\right]$} \\
\hline
\end{tabular}

次に, このダクトデータに空調機を組み込んだ場合の空調シミュ レーションを行う。なお，室圧・風量計算プログラムに組み込まれ た空調機のクーリングコイルの能力は，コイルの使用のほか, 風速 と列数および冷水量，冷水入口温度で決まり，冷水を作る能力は考 慮されていない。外気温度 $34\left[^{\circ} \mathrm{C}\right]$, 外気相対湿度 $65[\%]$, 室の顕 熱負荷 $76000[\mathrm{kcal} / \mathrm{h}]$ ，潜熱負荷 $24[\mathrm{~kg} / \mathrm{h}]$ とした計算結果を表 -4 中の I に示す。なお, 冷水コイルの幅 $1[\mathrm{~m}]$, 高さ $1.7[\mathrm{~m}]$, 冷水の 入口温度は $7\left[{ }^{\circ} \mathrm{C}\right]$, コイル列数は $8[$ 列], 冷水量は $377[1 / \mathrm{min}]$ とし た。計算の結果, 室温 $26.1\left[{ }^{\circ} \mathrm{C}\right]$, 相対湿度 $52.5[\%]$ とほほ設計值 通りとなっているのに対して, 室圧が $8.7[\mathrm{mmAq}]$ と非常に高く, 外 気量が $5956\left[\mathrm{~m}^{3} / \mathrm{h}\right]$ となっており, 設計值の $6000\left[\mathrm{~m}^{3} / \mathrm{h}\right]$ を満足してい ない。このことは，温湿度条件のみならず，室圧の制御を含めたダ クト設計を行う際には, 当然のことながらシステム全体の圧力バラ ンスの検討が重要であることをうかがわせる。このときのトータル 消費エンタルピーは $132405[\mathrm{kcal} / \mathrm{h}]$ である。

そこで, 外気量を $6000\left[\mathrm{~m}^{3} / \mathrm{h}\right]$ 以上とし，教室の室圧を $0.5[\mathrm{mmAq}]$ にするために調整を行う。その計算結果を表一 4 中のIIに示す。こ の際, 外気量の増加に伴う負荷の増加により教室の顕熱負荷を $71500[\mathrm{kcal} / \mathrm{h}]$ に隇少させた。計算結果は, 室温 $26.0\left[^{\circ} \mathrm{C}\right]$, 相対湿 度 $52.5[\%]$, 室圧 $0.5[\mathrm{mmAq}]$, 外気量 $6003\left[\mathrm{~m}^{3} / \mathrm{h}\right]$ である。このとき のトータル消費エンタルピーは $128375[\mathrm{kcal} / \mathrm{h}]$ である。

前述のダクトデータで室圧が高くなる原因の対策として, もとの ダクトデータに, 教室から外気への隙間をとり, 当該部分にフィル タ一を設置し，これと接する外気静圧を空調系統排気側外気圧と同 様として固定する方法を採った。このようにしておけば還気量を增 加させたのと同様の効果がある。この場合の計算結果を表 -4 中の III示す。計算の結果, 室温 $25.9\left[^{\circ} \mathrm{C}\right]$, 相対湿度 $53.3[\%]$, 外気 
導入量 $6283\left[\mathrm{~m}^{3} / \mathrm{h}\right]$ でほぼ設計值を満足しているが, 室圧が 1.2 [mmAq] と若干高い值となっている。このときのA H Uのトータル消 費エンタルピーは $135270[\mathrm{kcal} / \mathrm{h}]$ である。

室の顕熱負荷減少（顕熱負荷が $60000[\mathrm{kcal} / \mathrm{h}]$ に減じた場合）に 対するVAV開度による風量制御のシミュレーション結果を表一 4 中のIVに示す。V A V 機器の開度により, 吹出量を少なくすると 室温が下がり，室圧が上昇する。その原因は外気量が减少するため である。したがって，吸込側のVAVと外気導入量を同時に制御し なければならない。給気系統のVAV，還気系統のVAV，外気取 り入れ側ダンパの 3 ヶ所を同時に絞る方向で制御する。計算の結果 は, 室温 $26.0\left[{ }^{\circ} \mathrm{C}\right]$, 相対湿度 $52.2[\%]$, 室圧 $0.6[\mathrm{mmAq}]$, 外気導 入量 $6027\left[\mathrm{~m}^{3} / \mathrm{h}\right]$ ，AHUのトータル消費エンタルピー量 117457 $[\mathrm{kcal} / \mathrm{h}]$ である。室内負荷の減少によるV A Vの開度制御は, 省工 ネルギーにつながる ${ }^{16)}$ 一方, 室内への送風量を減らすとともに外気 導入量まで減少させるので, 室内炭酸ガス濃度によって必要な新鮮 空気の導入を図る必要がある。

室の顕熱負荷を $60000[\mathrm{kcal} / \mathrm{h}]$ としたままで，VA V機器を使用 せず, 外気導入量制御を行った場合のシミュレーション結果を表一 4 中の VK示す。室温 26.0 [ $^{\circ} \mathrm{C}$ ], 相対湿度 57.7[\%]，室圧 0.1 [mmAq]， AHUのトータル消費エンタルピー量 $152589[\mathrm{kcal} / \mathrm{h}]$ である。変 動熱量が小さい場合可能であるが, このケースは外気導入量の増加 により，投入エンタルピーの增大をまねいてしまう。
同じく室の顕熱負荷を $60000[\mathrm{kcal} / \mathrm{h}]$ としたままで, 冷水コイル の冷水流量制御のシミュレーション結果を表 -4 中のVIに示す。冷 水流量制御は, 冷水量を少なくして通過列数を 6 [列]に減じた。そ の結果は, 室温 $25.9\left[{ }^{\circ} \mathrm{C}\right]$, 相対湿度 $61.3[\%]$, 室圧 $0.7[\mathrm{mmAq}]$, AHUのトータル消費エンタルピー量 $109967[\mathrm{kcal} / \mathrm{h}]$ である。熱 量の変動に対する冷水流量制御は有効であるが, 微少なコントロー ルがし難い。また, チラーとの総合的検討が必要である。

\section{7： まとめ}

室・ダクト系の室圧・風量予測計算プログラムに温湿度計算を可 能とし, さらに冷水コイルのシミュレーションプログラムを組み込 み, 室内温度によるV A Vの開度制御およびV A V開度状態による ファン回転数制御，また, 冷水コイルの流量制御をおこなった際の 室・ダクト系の室温制御についての基礎的検討を行った。その結果, 空調シミュレーションに際して, 温湿度条件のみならず, 室圧の制 御を含めたダクト設計を行う際には, システム全体の圧力バランス, および全体の抵抗の変化に対する風量変化の検討が必要であるこ と。VAVの開度制御は冷水コイルの消費エンタルピーを減少させ, 省エネルギーにつながることが確認できた。以後は，1台の空調機 で異なった負荷のある室, あるいは 2 台の空調機の並列運転などの 空調シミュレーションを検討する。

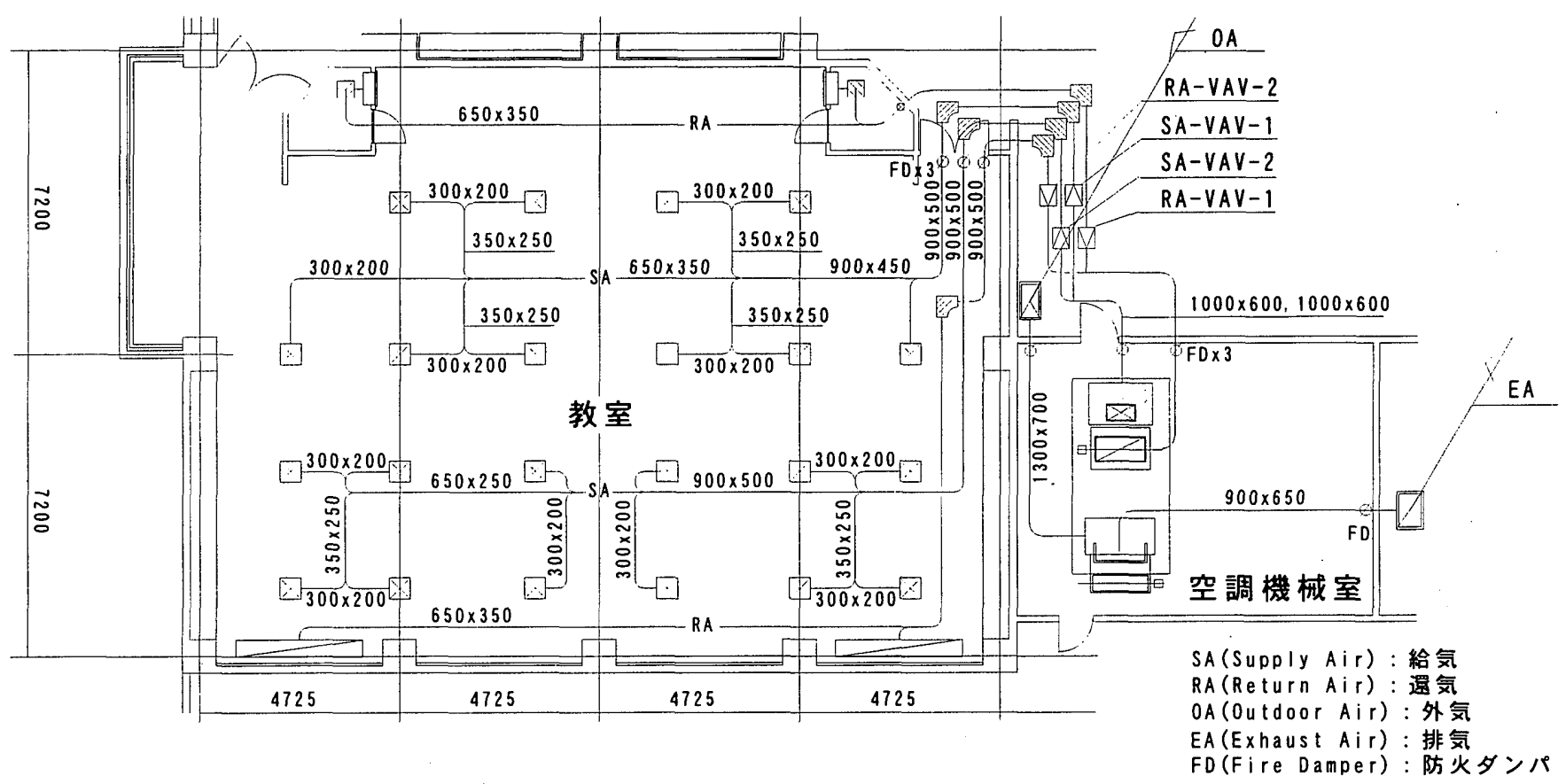

図ー2 概略ダクト平面図 
表ー4 空調シミュレーション計算結果

\begin{tabular}{|c|c|c|c|c|c|c|c|c|}
\hline & I & II & III & IV & $\mathrm{V}$ & VI & 単 位 \\
\hline \multirow[t]{2}{*}{ 教室熱負荷 } & 顕 熱負 荷 & 76000.0 & 71500.0 & 76000.0 & 60000.0 & 60000.0 & 60000.0 & {$[\mathrm{kcal} / \mathrm{h}]$} \\
\hline & 潜 熱 負 荷 & 24.0 & 24.0 & 24.0 & 24.0 & 24.0 & 24.0 & {$[\mathrm{~kg} / \mathrm{h}]$} \\
\hline \multirow[t]{3}{*}{ 教 } & 温 & 26.06 & 26.01 & 25.91 & 26.01 & 26.01 & 25.94 & {$\left[{ }^{\circ} \mathrm{C}\right]$} \\
\hline & 相対湿度 & 52.48 & 52.50 & 53. 32 & 52.19 & 57.67 & 61.25 & [\%] \\
\hline & 圧 & 8.7475 & 0.5031 & 1.2318 & 0.6378 & 0.0872 & 0.6815 & [mmAq] \\
\hline \multirow[t]{2}{*}{ 空調機出口側 } & 度 & 13.89 & 13.69 & 14.07 & 12.92 & 14.86 & 16.33 & {$\left[{ }^{\circ} \mathrm{C}\right]$} \\
\hline & 相対 湿 度 & 100.00 & 100.00 & 100.00 & 100.00 & 100.00 & 100.00 & [\%] \\
\hline \multirow[t]{2}{*}{ 空調機混気側 } & 度 & 28.60 & 28.82 & 28.56 & 29.76 & 31.40 & 28.74 & {$\left[{ }^{\circ} \mathrm{C}\right]$} \\
\hline & 相 対湿 度 & 59.02 & 59.57 & 59.73 & 61.04 & 64.49 & 64.36 & {$[\%]$} \\
\hline \multicolumn{2}{|l|}{ 外 気 量 } & 5956 & 6003 & 6283 & 6027 & 10293 & 6022 & {$\left[\mathrm{~m}^{3} / \mathrm{h}\right]$} \\
\hline \multicolumn{2}{|c|}{ トータル消費エンタルピー } & 132405.05 & 128374.50 & 35269.74 & 17456.86 & 152589.07 & 109967.13 & [kcal/h] \\
\hline
\end{tabular}

『参考文献】

1) 早川一也螎: 最新クリーンルーム設計ハンドブック, 施策研究セ ンター

2)後藤立夫:室・ダクト系における風量予測計算法に関する研究, 学位論文, 1995 年

3) 後藤立夫, 山崎均, 山下一彦:室・ダクト系の風量予測計算におけ る収束計算法, 日本建築学会大会学術講演梗概集, 1996 年 9 月

4) 中原信生, 朱熲心: 空調システムの動的シミュレーションの動向 とその意義, 空気調和・衛生工学 68-3,1994 年 3 月

5) 中原信生:制御と省エネルギ, 空気調和・衛生工学 49-11, 1975 年 11 月

6) 平山密, 塘一郎:室内外の温度差に基く自然換気量（第 1 報），日 本建築学会論文集 28,1943 年 2 月

7) 新津靖: 屋内空気状態の衛生学的研究（第 1 報）対流暖房と自然 換気の組合せに於ける暖房効果と換気量, 衛生工業協会誌 24-1〜 2,1950 年 1 月

（第 2 報）対流暖房と自然換気の組合せに於ける換気特性及び圧 力分布, 衛生工業協会誌 $24-1 \sim 2,1950$ 年 1 月

（第 3 報）室内外温度差と風力連合の場合の自然換気特性, 衛生 工業協会誌 24-11～12,1950 年 11 月

8)勝田高司: 自然換気に関する実験的研究, 東京大学生産技術研究 所報告 1-2,1950 年 8 月

9)石原正雄: 通風の実験的研究 (2開口間の距離と抵抗損失との関 係 1 ），日本建築学会研究報告 24,1953 年 10 月

開口の状態と抵抗係数, 日本建築学会研究報告 28-1, 1954 年 6 月
隙間の抵抗係数について, 日本建築学会研究報告 29-2, 1954 年 10 月

10)勝田高司, 寺沢達二, 片山忠久:金属製サッシの気密・我密に関す る実験的研究, 東京大学生産技術研究所報告 20-2,1970 年 8 月

11) S. Murakami, S. Kato, S. Akabayashi and K. Mizutani:WIND TUNNEL TEST ON VELOCITY-PRESSURE OF CROSS-VENTILATION RITH OPEN WINDOW, ASHRAE TRANSACTION, 1991, PART1

12）山崎均: 換気量計算法, 日本建築学会中国・九州支部研究報 告, 1987 年 3 月, 日本建築学会大会学術講演梗概集, 1987 年 10 月, 日本建築学会九州支部研究報告, 1988 年 3 月, 日本建築学会大会 学術講演梗概集, 1991 年 9 月

13) 山崎均, 後藤立夫, 貝塚正光, 渡辺俊行, 三不信博, 山下一彦: 自 然・機械力による通風・隙間換気量予測に関する研究 (既往研究 による基礎的考察その 1 ), 日本建築学会大会学術講演梗概 集, 1992 年 8 月

14) 山崎均, 後藤立夫, 貝塚正光, 渡辺俊行, 三不信博, 山下一彦, 前田 幸辉: 通風量予測に関する研究 (その 1 その 4), 日本建築学会 大会学術講演梗概集, 1993 年 9 月, 通風量計算システム, 日本建築 学会九州支部研究報告, 1994 年 3 月

15)井上宇市:空気調和ハンドブック, 丸善株式会社, p. 177, 1989 年 2 月

16）井上宇市，松本敏男：VAV方式における省エネルギ（第 1 報） インテリアソーンについて, 空気調和・衛生工学会論女 集, No. 0, 1976 年 3 月 